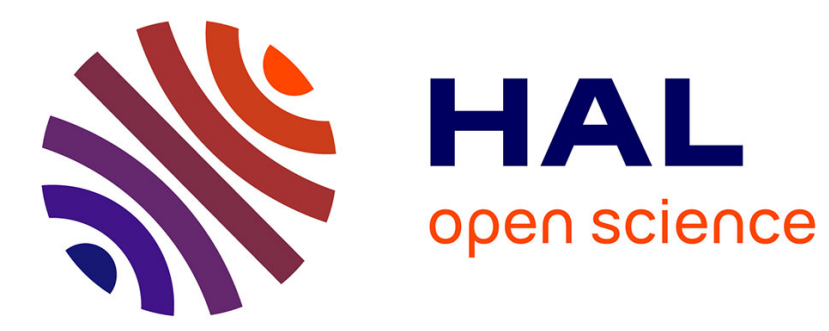

\title{
Variation in the Use of Pronouns as a Function of the Topic of Argumentation in Young Writers Aged 11 Years Emmanuèle Auriac-Slusarczyk
}

\section{To cite this version:}

Emmanuèle Auriac-Slusarczyk. Variation in the Use of Pronouns as a Function of the Topic of Argumentation in Young Writers Aged 11 Years. Argumentation, 2008, 22, pp.273-290. hal-00836125

\section{HAL Id: hal-00836125 \\ https://hal.science/hal-00836125}

Submitted on 20 Jun 2013

HAL is a multi-disciplinary open access archive for the deposit and dissemination of scientific research documents, whether they are published or not. The documents may come from teaching and research institutions in France or abroad, or from public or private research centers.
L'archive ouverte pluridisciplinaire HAL, est destinée au dépôt et à la diffusion de documents scientifiques de niveau recherche, publiés ou non, émanant des établissements d'enseignement et de recherche français ou étrangers, des laboratoires publics ou privés. 


\section{Editorial Manager(tm) for Argumentation \\ Manuscript Draft}

Manuscript Number:

Title: Variation in the use of pronouns as a function of the topic of argumentation in young writers aged 11 years

Article Type: Original Research

Section/Category:

Keywords: writing strategy, primary school, enunciation, socio-moral context.

Corresponding Author: Madame Auriac Emmanuèle, M.D.

Corresponding Author's Institution: IUFM d'Auvergne

First Author: Auriac Emmanuèle, M.D.

Order of Authors: Auriac Emmanuèle, M.D.

Manuscript Region of Origin:

Abstract: In our view, the ability to impose moral values which may be, to some extent, either shared or conflictual, influences the strategy adopted when writing argumentative texts. Our hypothesis is that the greater the socio-moral distance between the writers' representations (the writers in this case being children) and those of the recipients (here the parents), the more likely it is that writing will be successful. Three topics derived from a preliminary experiment and corresponding to significant differences in opinion between children and parents were tested in a population of 11-year-old pupils. The pupils had to write a letter designed to convince their parents about one of these topics. We analyzed the texts in order to identify the different configurations in the frequencies of use of the pronouns (frequencies of Je (I), Tu (You), II (He), On $(\mathrm{One} / \mathrm{We})$ ) and adverbs. These frequencies differed depending on the topic that was being written about (the moral context that is mobilized). 

Title: Variation in the use of pronouns as a function of the topic of argumentation in young writers aged 11 years

\section{Emmanuèle Auriac}

- Laboratoire P.A.E.D.I. : Processus d'Action des Enseignants : Déterminants et Impacts, JE 2432, Institut Universitaire de Formation des Maîtres d'Auvergne, Clermont Fd-

- Laboratoire de Psychologie Cognitive et Clinique, EA 3946, Université de Nancy 2-

eauriac@auvergne.iufm.fr ou emma.auriac@wanadoo.fr

Professional address:

I.U.F.M. d'Auvergne

3- Avenue Jean Jaurès

C.S. 20001

63407 Chamalières

France

Personal address:

Rue de la garde

63270 St Maurice es Allier

France 
Title: Variation in the use of pronouns as a function of the topic of argumentation in young writers aged 11 years

\begin{abstract}
In our view, the ability to impose moral values which may be, to some extent, either shared or conflictual, influences the strategy adopted when writing argumentative texts. Our hypothesis is that the greater the socio-moral distance between the writers' representations (the writers in this case being children) and those of the recipients (here the parents), the more likely it is that writing will be successful. Three topics derived from a preliminary experiment and corresponding to significant differences in opinion between children and parents were tested in a population of 11-year-old pupils. The pupils had to write a letter designed to convince their parents about one of these topics. We analyzed the texts in order to identify the different configurations in the frequencies of use of the pronouns (frequencies of Je (I), Tu (You), Il (He), On (One/We)) and adverbs. These frequencies differed depending on the topic that was being written about (the moral context that is mobilized).
\end{abstract}

KEY WORDS: writing strategy, primary school, enunciation, socio-moral context.

\title{
1 Introduction
}

The production of argumentative texts in school requires teachers to harmonize lesson schedules with the subject matter in question if their pupils are to be fully committed (Auriac-Peyronnet, 2001, 2003, 2004). It is, after all, difficult to get around the fact that arguing for arguing's sake can only ever be an academic exercise. In this article, we 
shall address the problem of the choice of subject as indicative of the cognitivediscursive strategies employed by writers. Clearly, integrating writing within an authentic communicative situation is important for the mobilization of genuine commitment on the part of writers (Golder, 1996). However, beyond this, what are the characteristics of the topics that are best able to promote argumentative activity? Does the relativization of the socio-moral values that necessarily underlie the handling of any subject matter (Golder, Percheron, Pouit, 1999) influence the (production) strategies underpinning the produced texts even in young pupils? Are pupils of this age, like adults, capable of benefiting from a socio-moral context in order to transform and perhaps optimize their productions?

\section{Theoretical framework}

In this article, we pursue a psycholinguistic and pedagogical tradition. We share the view that argumentation can, on the one hand, be taught to young pupils (Brassart, 1985, 1987, Dolz \& Pasquier, 1994, Dolz, 1996, Golder, 1996, Garate \& Melero, 2000) and, on the other, that children are receptive to this type of instruction, in particular as of the age of 10 years (Gombert \& Roussey, 1993, Roussey, Akiguet, Gombert, Piolat, 1995, Roussey \& Gombert, 1996, Gombert, 1997). We have already tested the ability of sequential mechanisms, consisting of progressive oral workshops, to improve writing (Auriac-Peyronnet, 1998, 1999). The results indicate that progressive train ing in the recognition of the different parameters involved in argumentative in teractions (presence of an opposed interlocutor, production of arguments, counter-arguments and examples, completion of statements) helps pupils free themselves of more strictly narrative strategies: in short, they gradually replace their narrative behavior with the automatic production of multiple arguments. However, it is a fact that argumentative strategies 
tend to be explored in oral learning situations rather than in written contexts before the age of ten years., And in all cases, writing follows speech.

The activity of text production is consequently complex and progressively structured and we believe that it is best studied within the theoretical framework of linguistic behavior that is defined as being derived from natural cognition (Espéret, Coirier, Coquin, Passerault, 1987; Coirier, Coquin-Viennot, Golder, Passerault, 1990). Summarized in the work of the logician J.B. Grize (Grize \& Apotheloz, 1976, Grize, 1990), this concept of natural cognition has more recently become intertwined with the subjects studied in the field of social and pragmatic psychology which considers conversation to be the everyday and superlative training of human reasoning and comprehension (see Trognon, 1995, 1997, 1999). This cross-over goes back to the idea that thought and language are constan tly in teracting (Vygotski, 1934/1997). The key question is: are young pupils able to benefit from their personal oral reasoning experiences in order to write better, and do they do so despite a lack of efficiency in argumentative writing which has been confirmed by a number of studies (see De Bernardi \& Antolini,1996, Pouit \& Golder, 1996, 1997, Ferréol, 1998, Golder \& Favart, 2003). To examine this, we first tested topics of writing with regard to which children do not share the same socio-moral values as their parents. Whatever the topic, the pupils only produced texts of a broadly justificatory nature without introducing any counterarguments (Auriac-Peyronnet \& Gombert, 2000, see Appendix). However, the adopted writing strategy seemed to change depending on the socio-moral subject matter they were asked to handle. It is this observation that prompts the investigations presented in this article. 


\subsection{An enunciative perspective}

We shall present the variations in pupils' writing strategies by studying the subsystem involved in the use of certain particularly interesting markers, i.e. the frequencies of use of the pronouns Je (I), Tu (You), Il(He), On (One/We) and of adverbs.

For the purposes of our study, we postulate that writers are receptive to the socio-moral standards influencing the choices they make when producing a text. In every area in which markers are chosen-1) absence/presence, 2) high or low frequency and 3) cue configuration - the writing process therefore brings together various cognitive operations. These operations are integrated in the more general activity of the conceptualization of speech activity (Clark, 1996). Markers, whether present or absentare subjective traces (Caron, 1983, 1984, 1987, Culioli, 1990, 2002). Numerous studies have also demonstrated that these linguistics indicators are helpful for the comparative

determination of the different types of produced speech (Bronckart \& al., 1985, Esperet, 1990, Golder \& Coirier, 1994, Golder, 1992a/b,1996, Auriac-Peyronnet, 1998, 1999, 2001). Of course, all markers are, in essence, multifunctional (Culioli, 1990, 2002). Numerous studies which have attempted to establish a relation between the use of markers and the underlying cognitive operations have been impaired by this phenomenon (for example Cadiot, 1991, Péroz, 1992, Auriac-Peyronnet, 1996, CaronPargue \& Auriac, 1997, Rossari, 2000). The experiments conducted by Ghiglione \& al. have identified the most revealing ind icators that can be observed when adult subjects have to adopt a position either in favor of or against their in itial attitude regarding a topic (Ghiglione, Kekenbosh \& Landré, 1995). Out of a set of ten pre-established categories, the authors identified four categories of marker indicative of differences of opinion. We reprint their table below. 


\section{Insert Table I here}

Only categories I, III, IV and $\mathrm{V}^{1}$ exhibit significant differences when subjects have to produce counter-attitudinal texts. The adults who produce these counter-attitudinal texts, that is to say texts that disagree with the point of view which they wish to defend, produce significantly more (in terms of frequency) markers of gen eral truth (the 'on' marker in French) and fewer modal markers or markers introducing a personal position (pronoun 'I' or statement of position "I think that..."). Overall, these linguistic indicators are more efficient in revealing the change of perspective than the number of arguments or counter-arguments (not significant, see appendix: Ghiglione, Kekenbosh \& Landré, 1995, Ghiglione \& Trognon, 1993). With regard to the use of adverbs, we also know that this is a reliable indicator of the cognitive operation of assuming responsibility (Golder, 1996). The acceptability of arguments gradually acquires a different form of adverbial surface marking as children progressively transform their representation of social truths. They initially consider the social consensus as an opposition between truth and falsehood before later coming to view it in terms of probability (Golder, Percheron \& Pou it, 1999).

In line with these authors, we consider that enunciative markers such as adverbs, indefinite pronouns ('that', 'it', 'one'), positional pronouns ('I', 'You', 'He') and formulations that in troduce a personal po sition ("I think that...", "It seems to me that...") are good lingu istic indicators for the study of the cognitive strategies (adhesion, doubt, precaution, persuasion) involved in writing. In theoretical terms, we can diagrammatically represent the mental model constructed in our situation of writing (a letter, see the experimental framework below) as follows:

\section{Insert Figure 1 here: the dialogical space}


In order to construct an argument that opposes the symbolic points of view held by the 'I' (symbolic position which represents the writer) and the "You" (symbolic position which represents the recipient), writers can avail themselves of certain potential aids. These aids represent their own views (I which presents their personal position), the beliefs that they attribute to others (You which presents the parents or other fictive audience), and points of view based either on a consensual, socially shared value (in French 'on' as a guarantor of shared truths), or on the beliefs of miscellaneous protagonists located between one's own (I) and the opposing positions (You). Such external protagonists $(\mathrm{He})$ could take the form of a friend, a member of the community, a friend of the opponent, a neighbor, the representative of a particular trend of opinion etc. For example, the low or high frequency of use of the French 'on' in the letter could reflect a preference to focus on a consensual perspective relating to general human experience (for example: for many pupils, it is 'normal' to have a bike) rather than to present an individual position in order to convince the audience (for example, me I like cycling). It is, of course, clear that the use of 'on' is a relatively unsophisticated way of adopting a position with regard to the truth and this marker is indeed used more frequently by young than by older children in the oral mode (see Jis a \& Vogüe, 2005). However, what is important here is to be able to follow the choices made by subjects of the same age.

\section{The experimental framework}

\subsection{The experiment}

Three significantly different topics were taken over from an initial study (AuriacPeyronnet \& Go mbert, 2000, see appendix) in order to construct three socio-moral contexts of influence. These topics were parties (source of high conflict between pupils 
and parents), clothes (average conflict topic) and bike (neutral topic). Eighty-two 11year-old children were asked to write a letter intended to convince their parents about one of the three topics in question. The pupils in each group were categorized on the basis of their general results in French (good, average, poor). It was the class teachers who assign ed the level on the basis of the pupils' results in various reading activities, their spoken and written productions, and exercises relating to the use of French: spelling, even if determined in this way, is, as our recent studies have shown (Auriac \& Favart, 2007), a factor that should be considered (with regard to this question, see also Bressoux, 2002). However, this factor does not constitute a major element in our study.

\section{Insert Table II here: experimental design}

\subsection{The production context}

In the task that we asked our participants to perform, the target audience was explicit since the children were required to write a letter to their parents (Alpha-Omega constraint protocol, cf. Brassart).

\section{Insert Figure 2 here: template letter}

\subsection{Our hypotheses}

Our core hypo thesis is that subjects will not organize their underlying reference points in the same way since they will adapt to the values underlying the various topics (party, clothes, bike). Several cognitive strategies should become evident in the respective and comparative frequency of use of the pronouns 'I', 'You', 'It', 'One' as well as in the use of adverbs. It is clear that texts do not consist solely of the organization of the

pronominal system. However, our study focuses only on this aspect. Each occurrence of a marker is considered to be an indicator of the local cognitive mobilization of a 
reference for the writer and, given this framework, the frequency of each marker should be equal. More specifically, we consider that the more conflictual (party) a topic is maximum disparity between children's and parents' viewpoints - the more the writers will maximize the use of referential positions (I, You, He, 'on') and, more particularly, have recourse to appeals to external protagonists $(\mathrm{He})$ to organize their productions. The frequency of use should be higher in the "party" context than in the other socio-moral contexts which were proposed (bike, clothes). In con trast, the more neutral (bike) the topic is, - low disparity between children's and parents' viewpoints -, the more effective an appeal to general truths (French 'on', or variants such as 'it is' or 'there is') should be since the common ground has already been constructed. The French marker 'on' should therefore predominate in this context (bike).

The hypothesis concerning the use of adverbs is less straightforward. We therefore propose no hypotheses here and simply conduct an exploratory study.

\subsection{Measures and treatments}

All the markers - whether a pronoun category I, You, He, She, 'on' (as well as impersonal pronouns such as 'that' or 'it's', see example below, 4.1.1.), a reference to a personal identification such as "My friend", "Jimmy", "The others", all the produced adverbs (not only the modal adverbs) - were considered. The frequency of use of each marker considered here was calculated as a percentage by dividing the number of markers present in the text by the number of words produced. We then used this frequency relative to the number of words produced as a variable in our statistical analyses. The length of each production was calculated on the basis of the number of words per text. We also categorized the texts as short (60 words or less) or long (61 to 200 words). We performed an initial analysis of variance with a multivariate general 
linear model of regression (GLM-Test multivariate, under SPSS 15.0) on all our topics. Additional linear regression analyses of variance were conducted in order to compare the texts and fine-tune our results. Our aim was to account for the fact that the frequency of each marker that was considered corresponded to a specific insertion in the global pronominal configuration of the text. Other factors of variation in production were considered, namely: a) academic level and b) length of the production.

\section{Results}

The topics of the texts used for the socio-moral production contexts (bike, clothes, party) did not result in any significant difference in terms of the mean length of production. The conflictual nature of the top ic is not therefore correlated with the length of production. By contrast, our study gives us an insight into the frequencies of use of the considered pronominal markers, configured as a function of the topic.

\subsection{Comparison of the topics: illust ration}

We shall now specify the different pronoun and adverb configurations for each of the examined writing topics (contexts of production).

\section{Insert Figure 3 here}

\subsubsection{The treatment of the consensual topic: "bike"}

The neutral topic (number 3: bike) gave rise to a very high level of appeal to a common ground ('on': shared true) that made it possible to mobilize culturally pre-constructed arguments. The presentation of this topic made use of shared opinions ("that's how", "one") to facilitate acceptance of the arguments.

Example text 
"Faire du vélo, c'est bien car cela muscle (...) cela permet de faire des promenades. Quand on ne sait pas quoi faire on peut aller faire du vélo. (...) Quand il est cassé on peut réparer son mécanisme." "Cycling, that's good because it makes you strong (...) it means you can go out. When you don't know what to do, you can always go cycling. (...) When it's broken, you can repair it." (It should be noted that the pronouns change in the English translation. In the original French, the marker is systematically the impersonal "on". However, it is necessarily translated as “You”.)

\subsubsection{The treatment of the intermediate topic: "clothes"}

As noted in the original study (Auriac-Peyronnet \& Gombert, 2000), the averagely conflictual context of production (number 2: clothes) led the pupils to produce justificatory (presence of arguments) and persuasive (frequent appeal to audience) texts. This is effectively the topic that best corresponded to the higher frequency of use of the classical enunciative marker You (see Figure 4).

Example:

"Je te rappelle que je n'ai plus cinq ans. Je sais quand même mes goûts et ce n'est pas les mêmes que les tiens. Je t'en supplie. Je t'adore. Je n'aime pas trop comment tu m’habilles."- "I want to remind you that I'm not 5 years old any more. I know what I like and that isn't what you like. I'm asking you, I love you, but I don't like the way you dress me."

\subsubsection{The treatment of the conflictual topic: "party"}

In contrast, the party text was treated in a more balanced way in terms of the uniform frequency of use of all the markers studied here, i.e. I, You, 'on', He and the adverbs. 


\section{Example :}

"Alors j'ai pensé que je pourrais y aller avec un copain plus grand, qui m'emmènerait le soir et me ramènerait la nuit. En plus il pourra me surveiller pour que je ne boive pas d'alcool. Je pourrai aussi me faire des copains que j'inviterais un jour à la maison.

Bien sûr les jours suivants je me coucherais tôt. (...) J'essaierai aussi de ne pas y aller trop souvent". - "So I thought I could go with an older friend who could take me in the evening and bring me back at night. He could also make sure that I don't drink any alcohol. I might also make so me friends whom I could invite back home one day. Of course, the days afterwards, I'd go to bed early. (...) And I'd also try not to go partying too often."

In this example, we observe the role that can be played by adverbs such as the references to friends ("He") in the produced text.

\subsection{First analysis: use of 'on' compared with You}

An initial analysis of variance using the general linear multivariate model including the dependant variables 'on' and 'You' yielded significant results in terms of the frequency of use of "on" $(\mathrm{F}(81,2)=3,712, \mathrm{p}<.03)$ in connection with the three proposed topics (party, clothes and bike). The pupils therefore constructed a significantly different representation of the situation (mental model) when confronted with our different topics. The pairwise comparison of the topics clothes $v$ s bike $(\mathrm{F}(52,1)=7,075, \mathrm{p}<.01)$ and party $v s$ clothes $(\mathrm{F}(55,1)=7,108, \mathrm{p}<.01)$ confirms this fact.

\section{Insert Figure 4 here}

It was the most neutral topic (number 3: bike) that resulted in the greatest frequency of use of 'on' (gross values) while it was the intermediate topic (number 2: clothes) that was most effective in leading writers to abandon this use of 'on'. It was therefore this 
intermediate topic that resulted in the greatest frequency of use of You as the intermediate reference person. As far as the comparison of the Clothes and Bike topics is concerned, the differences in the frequency of use of You were significant (You $\mathrm{F}(52,1)=10,368, \mathrm{p}<.002)$. The comparison between Party and Clothes revealed no significant difference in the frequency of use of You.

Thus, contrary to our central hypothesis, there was no progressive change in the use made of pronominal positional markers between the largely counter-attitudinal and the consensual topics. Instead, we observed a type of reorganization of all the uses made of the markers in question as a function of the way this distance between the parents' and the children's viewpo ints was processed. Pronouns therefore do indeed reveal the implicit (unconscious) strategies used by children to convince their audience as a function of the production context. Complementary analyses allow us to present additional results that question this mode of reconfiguring the system of pronominal use in each context of production (each topic).

\subsection{Study of the reconfiguration of the use of pronouns as a function}

\section{of topic}

The general linear regression analys is performed for all the texts combines the effects of the other introduced factors of variation: the pupils' academic level, the mean length of the production, and, as in the preceding analysis, the co-variation (degree of logical linkage) between the utilizations of the other employed markers -I, You, 'on', He/She and Adv-. 


\subsubsection{The impact of the pupils' academic level on the length of the production}

Independently of the type of topic, the pupils' academic level $(F(78,4)=3.85, p<.06)$ and the production of 'on' $(\mathrm{F}(78,4)=6.92 \mathrm{p}<.01)$ explain the length of production (short vs long texts, see figure 6): there is no in teraction between the use of 'on' and academic level. Thus, pupils with a higher academic level produced longer texts and the shorter the produced texts were, the more the pupils resorted to 'on' (in terms of frequency). In fact, when a more complete explanatory model (topic, frequency of use of 'on' and academic level) is adopted, it is the production of 'on' $(F(75,7)=9,73, p<.003)$ and the interaction between the type of text (topic) and the production of 'on' $(F(75,7)=4,13$, $\mathrm{p}<.05$ ) that explain the length of production (short vs long texts).

\section{Insert Figures 5 and 6 here}

The complementary regression analyses provide more detailed results for each type of topic considered on a two-by-two basis.

As far as the comparison of the clothes and bike texts is concerned (53 subjects), a significant trend can be observed between the length of production and the pupils' academic level $(\mathrm{F}(52,1)=2,7, \mathrm{p}<.07$-tendential effect only $)$. This observation echoes the main trend.

The analysis comparing the party and clothes topics ( 56 subjects) yields a significant effect concerning the use of 'on' (greater use of 'on' in connection with the party topic, see figure 4) which co-varied with the effective use of $\mathrm{He}(\mathrm{F}(55,30)=3,08, \mathrm{p}<.003)$. The length of production had a very small effect $(\mathrm{F}(52,3)=2,9, \mathrm{p}=.093$, tendency) which explained the use of 'on' with an additional effect of type of topic $(F(55,1)=3,950, p$ $<.02)$. No interaction was observed between the type of topic and the length of production. 
Finally, the analysis comparing the party and bike topics ( 55 subjects) indicates that the length of production $(\mathrm{F}(54,38)=2,35, \mathrm{p}<.04)$ and the effective use of $\mathrm{He}(\mathrm{F}(54,38)=3,66$, $\mathrm{p}<.004)$ co-varied significantly in relation with the concomitant use of 'on'. In this case, the shorter the texts were, the more effective the use of 'on' was, as was also the concomitant use of He. In other words, the (socio-moral) constraints influencing the decision to use the pivot 'on' reduced productivity in both contexts of production (bike or party) compared to the use of He.

\subsubsection{Variations in the use of the markers as a function of the type of topic}

From a strictly descriptive point of view (see Figure 3), it was the most conflictual topic (party) that provoked the greatest diversity - in terms of higher frequencies for each category - and breadth of utilization across the range of markers in question (I, You, He/She, 'On', Adv).

\subsubsection{Illustration of the use of "I" in comparison with other markers for all our topic s}

The frequency of use of I in all the texts (independently of the topic) can be explained by the co-variation in the use of You $(\mathrm{F}(81,1)=15,98, \mathrm{p}<.0001)$, the reduced use of 'on' $(F(81,1)=9,2, p<.005)$ and the effective use of adverbs $(F(81,1)=10,72, p<.002)$. When pupils use the pronoun I more, they use 'on' less and also employ adverbs in their productions. In fact, for all the topics, this utilization of I was significantly dependent on the pupils' academic level $(\mathrm{F}(81,1)=4,41, \mathrm{p}<.04)$. Thus the pupils with a low academic level used the pronoun I more frequently than the good or average pupils, and did so independently of the topic (see figure 7).

\section{Insert Figure 7 here}


Independently of the type of topic, 'I' can function in a configuration in which 'on', You and the 'adverbs' are employed together. We therefore have to consider the idea that 'I' can create an initial preferred configuration when used with 'You' alone as part of the 'I/you' dyad (38\% of explained variance), as a secondary adjunction with the use of 'adverbs' ( $27 \%$ of explained variance), and, finally, is necessarily associated with a low level of production of the pronoun 'on' ( $26 \%$ of explained variance). This is consistent with the fact that it tends to be pupils with a higher academic level who use 'on' in their texts. We shall illustrate this correlated use of personal involvement (pronoun I) and adverbs (see below: bien (well, translated below as "just"), quand même (even though, translated below as "anyway"), trop (too much, translated below as "really"), toute (all), maintenant (now)) in a text produced by a pupil with a low level of French.

Example text produced by a pupil with a low academic level:

"Si j’avais vingt ans (...) je pourrais bien mettre ce que je veux qua nd même ! et puis je suis assez grande pour décider ce que je dois mettre maintenant (...) De toutes façons vous n'allez pas me suivre to ute ma vie. (...) Vous m’énervez trop !". "If I was twenty years old (...), I could just wear whatever I want anyway! And I'm old enough to decide what I want to wear now (...) Anyway, you won't be able to follow me around all my life (...) You really annoy me!"

It appears that the investigation of this interdependence between these uses of 'I' and the other markers might represent an interesting avenue of research in the field of young writers' productions. 


\subsubsection{Coordin ated use of 'You', 'on' and 'He' as a function of the topic}

Just as was observed for 'on' and 'You' in the main analysis, the secondary analyses revealed a small tendency in the frequency of use of 'He' for all types of topic (party> bike $>$ clothes, $t=1,694, p=0.094)$. Topic difference explains the use of 'He', independently of the pupils' academic level, the length of their productions, or the correlated use of adverbs and the pronouns 'I', 'You', 'on'. It would therefore appear that the use of 'He' on its own could be a good indicator making it possible to distinguish between our topics. In fact, the use of 'He' (which was observed more frequently in the "Party" conflictual topic) was not correlated with the pupils' academic level. The "He" marker might not seem to be a source of high and significant differentiation, undoubtedly becau se of its low level of utilization in the data which we collected (see figure 4): even though it was observed more than 'on', in which case the 'I/you' dyad is pivotal (as in the clothes topic).

The comparison of the Clothes and Bike topics is of interest if we wish to understand the linguistic context in which subjects use 'You'. This analysis indicates that the enunciative pivot 'You' operates as an alternative to the use of 'on' $(F(52,10)=5,72$, $\mathrm{p}<.03)$ and the use of $\mathrm{He}(\mathrm{F}(52,10)=7,04, \mathrm{p}<.02)$. There was an interaction between the type of topic and the use of 'on' $(\mathrm{F}(52,10)=4,49, \mathrm{p}<.04)$. The introduction of a strong dialogical perspective between 'You' and 'I' ( Clothes topic) reveals a specific writing strategy for this topic (clothes) characterized by the concomitant use of 'You' and 'on'.

\section{Conclusion and discussion}

The specifically developmental inability to produce counter-arguments at the age considered in our study (i.e. an ability which is effectively achieved at about 13-14 years, see Golder, 1996) might induce pupils to use other mechanisms to achieve their 
argumentative objectives. As predicted in the preliminary study which was conducted with adults (Ghiglione, 2003, see the theoretical framework), the management of pronominal configuration as sole indicator is a good way to study writing strategies (despite the multifunctional nature of these markers). The three topics we used were processed in different ways by the pupils (which were contrasted in our analysis of the linguistic markers). Our results can be summarized in three ways: 1) the distribution of pronoun frequencies characterizes the context of socio-moral production (our top ics), 2) certain external factors influence the variation in the frequency of our linguistic markers (pronouns and adverbs), and 3) finally; linguistic markers act as factors of co-variation in the internal linguistic variation observed during the writing process.

First, within the framework of the data collected here, the pronouns 'on', 'You' and 'He' are good indicators which make it possible to specify the contexts of production (topic). Further studies will need to be conducted in order to confirm these results. However, the use of the pronoun 'on' is radically different from that of 'You'. To a lesser extent, 'He' reveals a particular aspect of the deployment of the dialog structure of the produced text. Our linguistic markers should be considered as indicators for the specification of variations in production contexts in future studies.

Secondly, the use of 'on' is related to poor productivity. The pupils who made frequent use of 'on' also produced shorter texts. Consequently, the use of 'on' should be considered to be both an indicator of the ability to use the 'on' truth (as a conceptual constraint -moral context-) and/or as an indicator of a strategy that is employed by pupils to make their productions more economical (linguistic constraints). Thus, the handling of the "on truth" (as a conceptual constraint) in response to a pedago gical mechan ism can be considered to be a factor that results in a reduction in the len gth of 
productions (linguistic result): it would be less easy to develop an expansive writing process when recourse to the consensual 'on' is possible. In addition to these remarks concerning the use of 'on', the use of 'He' was correlated with the production of longer texts, irrespectively of the pupil's academic level. In contrast, the use of 'I' was primarily observed among pupils with a poor academic level. In consequence, the frequencies of the linguistic markers 'I', 'on' and 'He' are indicators of interest when specifying the influence of academic level or explaining productivity.

Thirdly, as far as the co-variations between the individual markers considered in this study are concerned, our results show that the more frequently subjects use 'on', the less they use 'I' or 'You' in the same production. Consequently, the use of 'I' tends to covary with 'You', less often with the adverbs and sometimes with 'on'.

What are the consequences for both academic development and future research? As far as the co-variation in the use of markers ('I', 'You', 'On', 'He' and adverbs) is concerned, teachers may not find enhanced knowledge of this phenomenon to be of value. At the same time, when we consider the use of adverbs, it is somewhat surprising to observe that some uses of 'I' result in a greater use of adverbs and that this use of adverbs occurs in the academically less advanced pupils. It is often thought that such pupils have less sophisticated linguistic tools at their disposal. However, in our study, we observed that the lower-level pupils were able to make judicious use of adverbs. The strategy underlying the use of 'I' and 'adverbs' may perhaps be a good indicator enabling us to identify pragmatic competences which are not generally considered at school level (see Auriac, 2007). To argue is not only to adduce arguments and counterarguments. It also involves managing the interface with the audience in both written and oral situations. The writer's involvement in his or her text, in particular when the text 
which has to be produced is argumentative in nature, is doubtlessly an extremely complex affair, even for young writers.

If this is the case, then the consensus concerning the "on truth" could take the form of a Mitsein (recourse to collective society, see Maisonneuve, 1950/2002, p.39/41) which assists young pupils in pre-planning their position, whereas in the case of a major sociomoral conflict, the "on truth" may perhaps be constructed dynamically as the text is written. The studies of the co-variation of the pronominal configurations demonstrates this possibility through the comparison of the Bike and Party topics. The absence of a pre-established Mitsein (as in our Party topic) demands the progressive construction of the "on truth" which takes place gradually by making the maximum possible use of the other potential enunciative instances: The Party topic is the most suitable context for the use of different pronouns, 'I', 'You', 'He', 'on'. Although the Party texts were no longer than the others, they were more balanced in terms of the frequency of our linguistic markers. In such cases, the texts, that are still justificatory in nature, are more highly developed. To summarize, the best material to get pupils to write, in terms of using a wide range of referential pivots, is -as we predicted- the familiar, highly conflictual material, the party. Within this perspective, our study confirms the findings of other research (Gombert, 1997), albeit with a new set of indicators.

The opposition between justification and negotiation, useful though it is for describing developmental skills (Golder, 1996), is not, in our opinion, sufficient to account for the general ability to argue in young students. Our linguistic indicators help facilitate the study of the unconstrained justificatory texts produced by young students. They seem to us to be a good way to help researchers qualify the cognitive processes at work in young writers. 
If pupils are receptive to the underlying values that are implicitly suggested by the proposed topics then they are also able to vary, even if inexpertly, their writing strategies and are able to make valid enunciative choices that testify to the existence of the cognitivo-discursive strategies that are at work. Argumentation is not just the juxtaposition of theories. It implies reasoning about the world and requires writers to adapt their productions to their belief systems: it also requires subjects to organize the knowledge which might be thought to underpin the use of pronouns and adverbs which, in turn, contribute to the deployment of this knowledge.

\section{NOTES}

\footnotetext{
${ }^{1}$ In italic in the table

${ }^{2}$ Here, we use the results up to a threshold of $p=0.1$ in order to ind icate the tendencies at the limit values given the largely exploratory nature of these analyses. This will help op en up avenues of investigation that may be either invalidated or confirmed by subsequent studies.

${ }^{3}$ Id em
}

\section{REFERENCES}

Auriac, E. : 2007, L'exercice des compétences pragmatiques à l'école primaire: intérêt et résultat, Enfance, 2007(4)

Auriac-Peyronnet, E. : 2004, 'Pensée reflexive et habiletés argumentatives', in R. Pallascio, M-F Daniel \& L. Lafortune, Pensée et réflexivité. (pp. 151-182), Presses de l'Université du Québec, Montréal.

Auriac-Peyronnet, E. (dir). : 2003, Je parle... tu parles... nous apprenons. Coopération et argumentation au service des apprentissages, DeBoeck Université, Paris, Bruxelles:

Auriac-Peyronnet, E. : 2001, The impact of an oral training on argumentative texts produced by Ten-and Eleven-year-old Children: exploring the relation between Narration and Argumentation, European Journal of Psychology of Education, Vol XVI, n², 299-317. 
Auriac-Peyronnet, E. : 1999, Argumenter en CM1 et CM2: le croisement de l'oral et de l'écrit, Troisième congrès International d'Actualité de la Recherche en Education et Formation, Bordeaux, 28-30 Juin 1999.

Auriac-Peyronnet, E. : 1998, Effects of Oral practice and Cooperative discussion on Argumentative Text writing by 10-12 Year Old Children, Communication Second international workshop on argumentative text processing, June 30, July 1, Poitiers, France.

Auriac-Peyronnet, E. :1996, Construction d'un rôle d'autorité autour du fonctionnement de l'opérateur discursif «bon»dans l'échange conversationnel, Interaction \& Cognitions, 1(2-3), 293-327.

Auriac, E., \& Favart, M. :2007, Passage d'un avant texte au texte dans des écrits scolaires de type argumentatif. Langue Française, 115.

Auriac-Peyronnet, E. \& Daniel, MF. : 2003, The Specifics of Philosophical Dialogue: A Case Study of Pupils Aged 11 and 12 Years, Thinking. 16,1 23-31.

Auriac-Peyronnet, E. \& Gombert A.: 2000, Effects of collective moral values on argumentative text produced by 11-13 years old children. Third Workshop on Argumentative Text Processing, Earli Sig-Writing, Verona, September 6.

Brassard, D. :1985, Les Enfants comprennent-ils des Enoncés Argumentatifs?, Repères, $65,15-21$.

Brassard, D. G. :1987, Le Développement des Capacités Discursives chez l'enfant de 8 à 12 ans: Le Discours Argumentatif (étude didactique), Thèse de doctorat. Strasbourg.

Bressoux, P. :2002, Le jugement des enseignants sur la valeur scolaire des élèves, In P. Bressoux (Dir.), Les stratégies de l'enseignant en situation d'interaction, (pp.47- 
74). Note de synthèse pour Cognitique : Programme Ecoel et Sciences Cognitives. Février 2002

Bronckart, J.P. et al. :1985, Le Fonctionnement des Discours. Un Modèle Psychologie et une Méthode d'Analyse, Delachaux-Niestlé, Paris.

Cadiot, P. :1991, De la grammaire à la cognition. La préposition POUR, Ed du CNRS, Paris.

Caron, J. \& al. :1983, La pensée naturelle, structures, procédures et logique du sujet, Groupe de Recherche Ontogénèse des Processus Psychologiques, Université de Rouen, Publication de l'Université de Rouen, 86, Presses Universitaires de France, Paris.

Caron, J. : 1984, Les opérateurs discursifs comme instructions de traitement. Verbum, $n^{\circ}$ spécial: l'interlocution, $7,149-164$.

Caron, J. :1987, Pour une approche psycholinguistique de l'argumentation, in Le Bonniec, G., (ed), Connaître et le dire, Mardaga, Bruxelles.

Caron-Pargue, J., \& Auriac, E.: 1997, Etude psycholinguistique de la marque conversationnelle bon dans une interaction cognitive. In J. Bernicot, J. CaronPargue, \& A. Trognon, Conversation, Interaction, et fonctionnement cognitif (pp. 151-185), Presses Universitaires de Nancy, Nancy.

Clark, H.H. :1996/2002, Us ing Langage, United Kingdom University Press, Cambridge. Coirier, P., Coquin-Viennot, D., Golder, C., \& Passerault, J.M. :1990, Le traitement du discours argumentatif: recherches en production et en compréhension. Archives de Psychologie, 58, 315-348. 
Culioli, A. :2002, Variations sur la linguistique. Entretien avec Frédéric Fau, Klincksieck, Langres

Culioli, A. :1990, Pour une linguistique de l'énonciation, Opérations et représentations, Tome 1., Ophrys, Paris.

De Bernardi, B. \& Antolini, E. :1996, Structural differences in the production of written arguments, Argumentation, 10 (2), 175-196.

Dolz, J. \& Pasquier A. :1994, Enseignement de l'Argumentation et Retour sur le Texte (1), Repères, 10, 163-181.

Dolz, J. :1996, Learning argumentative capacities. A study of the effects of a systematic and intensive teaching of argumentative discourse in 11-12 year old children, Argumentation, 10, 2, 227-251.

Esperet, E., Coirier P., Coquin, D. \& Passerault, J.M., :1987, L’implication du locuteur dans son discours: discours argumentatifs formel et naturel, Argumentation. 1, $149-168$.

Esperet, E. :1990, De l'Acquisition du Langage à la Construction de Conduites Langagières. in Netchine-Grynberg G. (dir), Développement et fonctionnement Cognitifs chez l'Enfant, Presses Universitaires de France, Paris.

Ferréol, M. :1998, Role of the reading level on argumentative text reconstruction in 11 year-old children. Paper Second international workshop on argumentative text processing, June 30, July 1, Poitiers, France.

Garate, M. \& Melero, M.A., :2000, Intervention in the psychological process involved in the writing of argumentative texts in sixth year of primary education. Third Workshop on Argumentative Text Processing, Earli Sig-Writing, Verona, Septembre 6. 
Ghiglione, R. \& Trognon, A. :1993, Où va la pragmatique, de la pragmatique à la psychologie sociale, Presses Univ ersitaires, Grenoble.

Ghiglione, R., Kekenbosch, C. \& Landré, A. :1995, L'analyse cognitivo-discursive, Presses Universitaires, Grenoble

Golder, C. \& Coirier, P. :1994, Argumentative Text Writing: Developmental Trends. Discourse Processes, 18, 187-210.

Golder, C. :1992a, Argumenter: de la Justification à la Négociation, Archives de Psychologie, 60, 3-24.

Golder, C. :1992b, Justification et négo ciation en situation monogérée et polygérée dans les discours argumentatifs, Enfance, 46, 99-112.

Golder, C. (1996). Le développement des discours argumentatifs, Delachaux \& Niestlé, Lau sanne

Golder, C., Percheron, A. \& Pouit, D. :1999. Les choses ne sont jamais totalement vraies ou totalement fausses. Point de vue sur la conduite communicative d'argumentation en production écrite, Enfance, 2, 99-110.

Golder, C. \& Favart, M. :2003, Argumenter c'est difficile... oui, mais pourquoi? Approche psycholinguistique de la production argumentative en situation écrite. Etudes de Linguistique Appliquée, 130, Avril-Juin, 187-209.

Gombert, A. \& Roussey, J.Y. :1993, 'Computer-assisted training effects on argumentative text writing skills in children', in G. Eigler, \& T. Jechle (Eds.), Writing. Current trends in European Research (pp.183-196), Freiburg: Hochschul Verlag. 
Gombert, A. :1997, Comment les rédacteurs de 10 à 13 ans justifient-ils et argumentent-ils? Rôle du thème rédactionnel, de l'opinion consensuelle et de la thèse à défendre, Thèse de psychologie, Aix en Provence.

Grize, J.B. \& Apotheloz, D. :1976, Matériaux pour une logique naturelle, Travaux du centre de recherches sémiologiques, 29, Université de Neuchâtel, Mai 76.

Grize, J.B. :1990, Logique et langage, Ophrys, Paris.

Jisa, H., \& Viguié, A. : 2005. A developmental perspective on the role of 'on' in written and spoken expository texts. Journal of pragmatics, 37, 125-142.

Maisonneuve, J. :1950/2002, 'La personne et les cadres sociaux. Ressort et formes du lien social', in J. Maisonneuve, La psychologie sociale, (pp. 25-47), Presses Universitaires de France, Paris.

Péroz, P. :1992. Systématique des valeurs de bien en français contemporain. Librairie Droz, Paris, Genève

Pouit, D. \& Golder, C. :1996, Peut-on faciliter l'argumentation écrite ? Effets d'un schéma de texte, d'une liste d'idées et d'un thème familier, Archives de Psychologie, 64, 179-199.

Pouit, D. \& Golder, C. :1997, Il ne suffit pas d'avoir des idées pour défendre un point de vue. La récupération des idées peut-elle faciliter la production écrite d'une argumentation chez les enfants de 11 à 17 ans, Revue de Psychologie de l'Education, 3, 33-52.

Rossari, C. :2000, Connecteurs et relations de discours : des liens entre cognition et signification, Presses Universitaires de Nancy, Nancy.

Roussey, J.Y. \& Gombert, A. :1996, Improving argumentative writing skills: effect of two types of aids, Argumentation, 10, 283-300. 
Roussey, J.Y., Akiguet, S., Gombert, A. \& Piolat, A. :1995, Etude de l'utilisation du schéma argumentatif par des rédacteurs âgés de 8 à 11 ans, Enfance, 2, 205-214.

Trognon, A. :1995, La fonction des actes de langage dans l'interaction : l'exemple de l'intercompréhension en conversation, Lidil, 12, 67-85.

Trognon, A. :1997, Conversation et raisonnements, in J. Bernicot, J. Caron-Pargue, J, \&

A. Trognon. Conversation, interaction et fonctionnement cognitive, (pp. 253-282).

Presses Universitaires, Nancy,

Trognon, A. :1999, Eléments d'analyse interlocutoire, dans Gilly M., Roux J.P.,

Trognon A., Apprendre dans l'interaction, (pp.69-94), Presses Universitaires, Nancy \& Publication de l’Université de Provence, Aix-en-Provence.

\section{Insert Figures (1 to 7) and tables (I and II)}

Figure 1: dia logical space

DIA-LOGICAL SPACE

To write

\begin{tabular}{|c|}
\hline It-truth (On-Vrai) \\
consensual opinions \\
It, we (On) \\
I (Je)
\end{tabular}

Figure 2: Model letter

Dear Parents, I would like to have TOPIC, but I know you don't agree, 
So it would be

great if I had TOPIC.

Figure 3 here: Comparison of the use of markers "I", "You", "On", "He" and adverbs

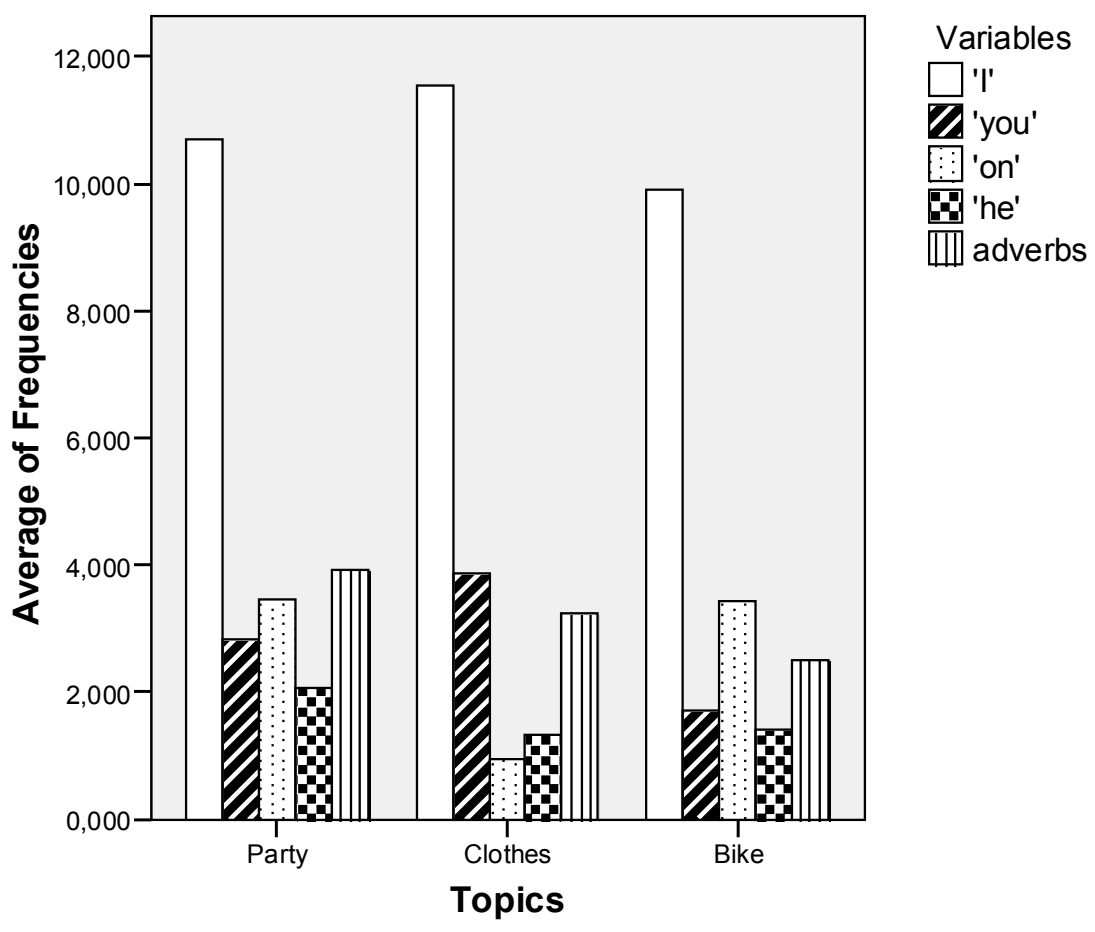

Figure 4: Comparis on of the use of "You" and French "On" 


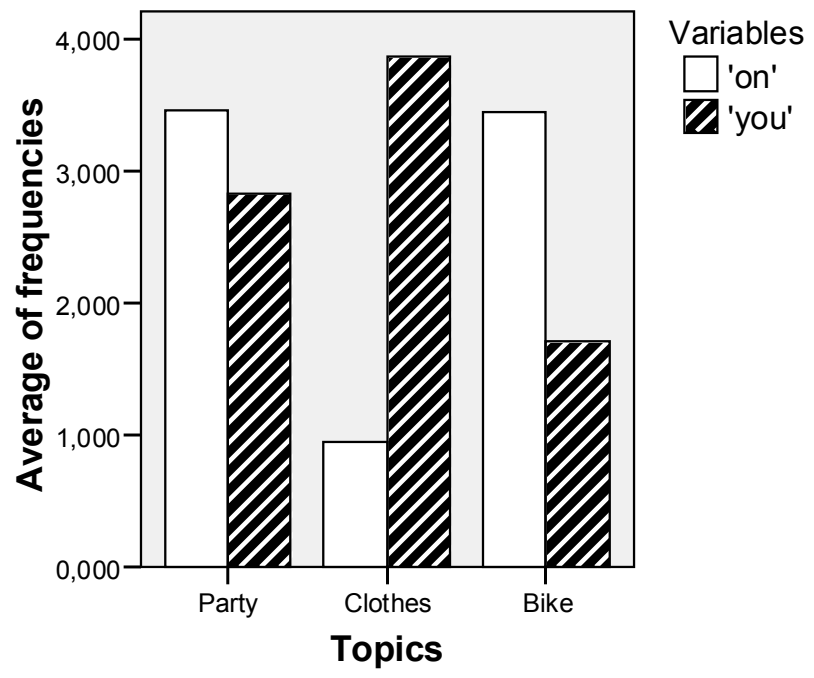

Figure 5: The relations between the pupils' academic levels and the length of the productions (number of words)

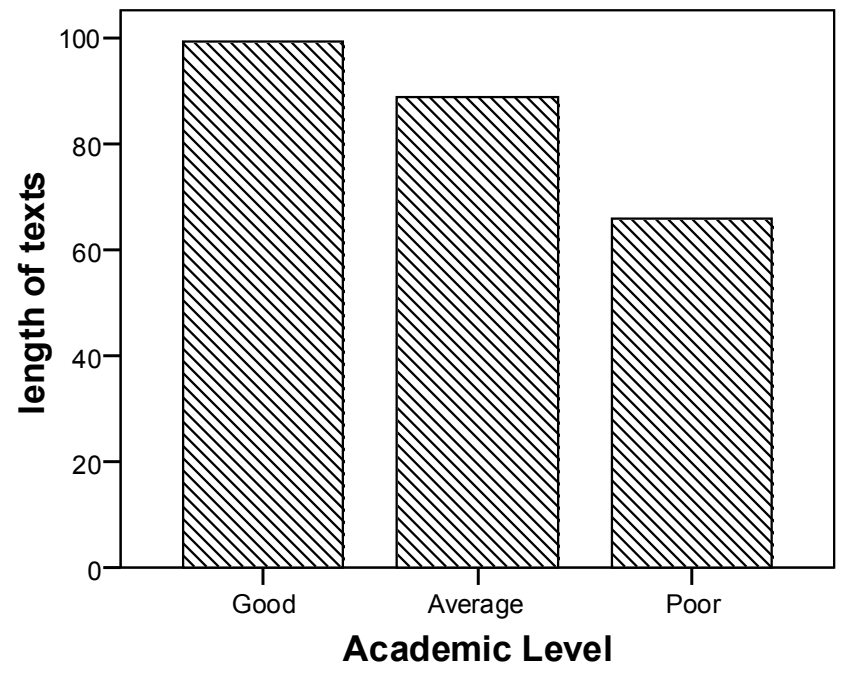

Figure 6: The relation between the use of French 'on' and the length of production (cont rast between short texts $-<60$ words- and long te xts -60 to 200 words-) 


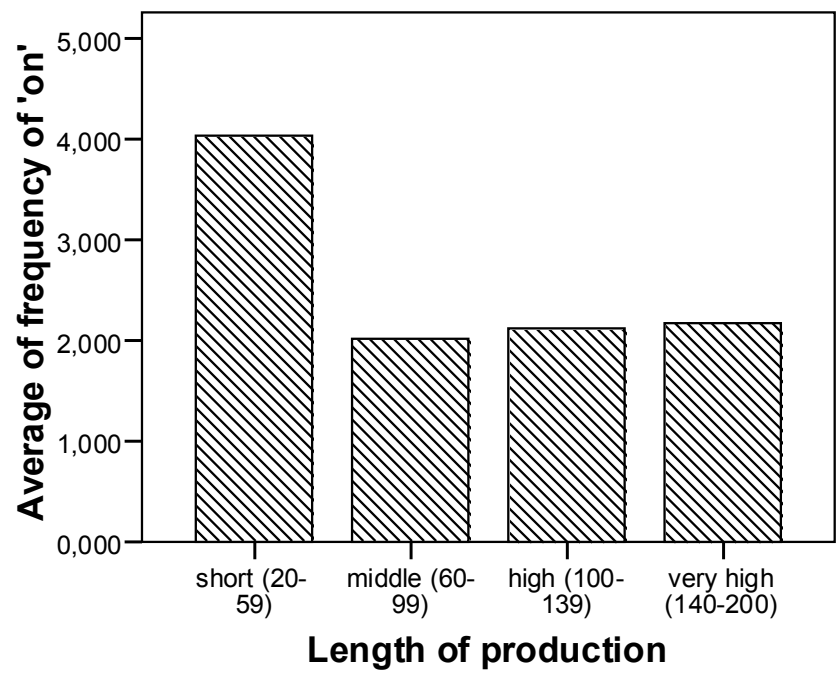

Figure 7: The use of "I" and adverbs as a function of the pupils' academic level

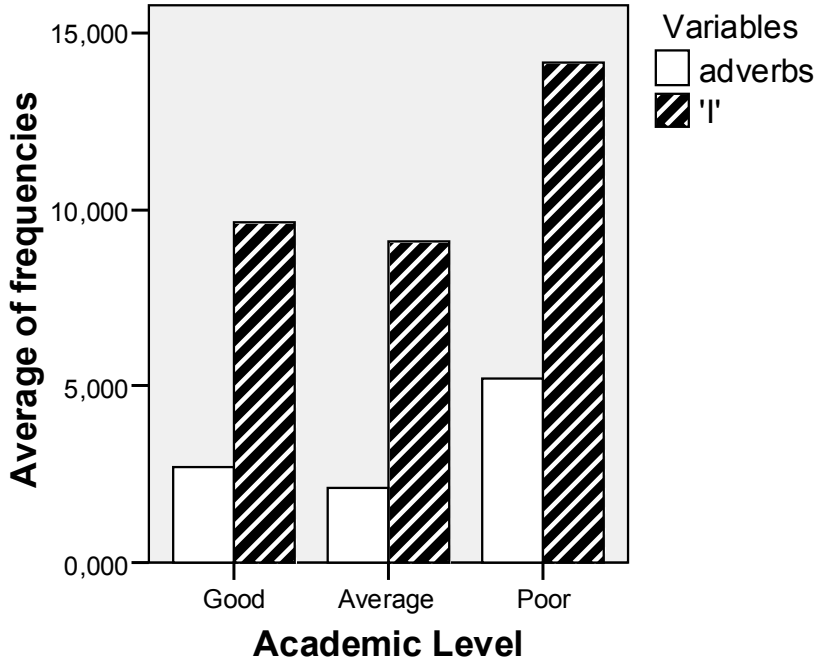

Table I: The different categories of marker

Categories

Examples

\begin{tabular}{|l|l|} 
I. Deictic & Je moi ma mon (I me my) \\
\hline II. Simple argumentative marker & $\begin{array}{l}\text { Car, parce que, en effet (since, } \\
\text { because, in fact) }\end{array}$ \\
\hline
\end{tabular}




\begin{tabular}{|l|l|}
\hline III. Modal adverb & certainement (certa inly) \\
\hline IV. Introductory locution & Je pense que (I think that) \\
\hline V. Indefinite Pronoun & On + nous (One, we) \\
\hline VI Counter-argumentative markers & Bien que, même si (even if, even \\
though) & Il faut (You have to) \\
\hline VII. Modal Auxiliaries & Non seulement, ... mais aussi (Not \\
\hline VIII. Correlative argumentative markers & only ... but also) \\
\hline IX. Non-declarative form & Interrogative, imp erative... \\
\hline X. Passives & Agent "by" \\
\hline
\end{tabular}

Taken from Ghiglione \& Trognon, Où va la pragmatique, 1993

Table II: Experimental design

\begin{tabular}{|c|c|c|c|}
\hline & Group 1 $(n=26)$ & Group 2: $(n=27)$ & Group 3: $(n=29)$ \\
\hline & Neutral topic & Average topic & $\begin{array}{c}\text { Highly conflictual } \\
\text { topic }\end{array}$ \\
\hline & BIKE & CLOTHES & PARTY \\
\hline Good level & $\mathbf{1 1}$ & $\mathbf{1 1}$ & $\mathbf{1 1}$ \\
\hline Average level & $\mathbf{9}$ & $\mathbf{7}$ & $\mathbf{1 0}$ \\
\hline Poor level & $\mathbf{6}$ & $\mathbf{9}$ & $\mathbf{8}$ \\
\hline
\end{tabular}

Key: Experimental factors: Factor $1=$ topics (neutral, a verage, highly conflictual);

Factor 2 = Level (good, average, poor); Dependent variables: number of enunciative markers in each category.

\section{APPENDIX:}

Table III: List of topics in the pre-experiment (extract from Auriac \& Gombert, 2000) 
According to you, to dress as you want is:

According to your parents, to dress as you want is:

0

1

$2 \quad 3$

4

5

Level 0 = "not good a t all..." Level 6 = "really good...."

\begin{tabular}{|c|c|c|}
\hline Major difference & Average differen ce & Small difference \\
\hline $\begin{array}{l}\text { Party until 1 in the } \\
\text { morning (2.36) } \\
\text { Horror film (2.04) } \\
\text { Video games (1.84) } \\
\text { Cinema alone (1.8) } \\
\text { Cutting hair (1.6) } \\
2 \text { nights with a friend (1.5) } \\
\text { Television (1.44) } \\
\text { Friend's homework (1.32) }\end{array}$ & $\begin{array}{l}\text { Choose your own clothes } \\
\text { (1.28) } \\
\text { Walk ing after school (1.24) } \\
\text { Playing late in the street (1.2) } \\
\text { Mobile telephone (1.16) } \\
\text { Music and homework (1.12) } \\
\text { Risk sports (1.12) } \\
\text { Abroad alone (1.12) } \\
\text { Sweets (1.04) } \\
\text { Key to the house (1.04) }\end{array}$ & $\begin{array}{l}\text { Branded trainers } \\
(0.92) \\
\text { Pocket money } \\
(0.88) \\
\text { Jeans }(0.84) \\
\text { Hood }(0.8) \\
\text { Umbrella }(0.76) \\
\text { Homework }(0.64) \\
\text { Bike }(\mathbf{0 . 3 9})\end{array}$ \\
\hline
\end{tabular}

Key: the three selected topics are printed in bold type. The topics are listed in descending order as a function of the significant difference in viewpoint between the children and their parents, as perceived by the children.

\section{NOTES}

\footnotetext{
${ }^{1}$ In italic in the table
} 


\section{ARGU 374 \\ Revision of initial Manuscript : Argumentation as epistemic distance : a study of the impact of production contexts on writing strategies in young French pupils.}

As the critical and suggestion from the reviewer $n^{\circ} 1$, I restricted the presentation to the specific interest concerning the "description of the linguistic behaviour". I reduced the theoretical framework (strictly as suggested all after page 4). I try to be more clear and simplify the vocabulary . I delete the reference to "negotiating space", "distance", "dialogical space"... to a sole reference: I replace "epistemic" distance in reference to the difference (implicitly socio-moral) between the three topics (as suggested by the second reviewer). I explain what is a justificatory text. I delete the references to the schema theory (it was not indispensable). I don't transform the abstract which was judged good. I insist on the interest to study the strategies of writing under the use of the pronouns: it is the new vision related by my contribution to the field of argumentation. I relate more specifically the conclusion with the results. I simplify the result to more circumscribe the importance of each result: I , in this sense, transform the figure: they are more clear and more simple. I more explain this result because the reviewer say that "good teachers already know that there is a positive correlation between the conflictual nature of topic and the length of production". But in fact, this paper demonstrates that the length of production is not correlated with degree of conflict but with the strategy of writing. And finally, some study demonstrate that the academic level judged by teacher are perhaps more important than academic level established with standardized. I introduce a reference in this way.

As the critical and suggestion from the reviewer $\mathrm{n}^{\circ} 2$, I take into account all the suggestions (clarity, orthographic error, methodological suggestion -design table for example, etc.). Je poursuis en français dans la mesure où ce reviewer s'est exprimé en langue française, ce qui sera plus facile pour moi.

J'ai resséré l'article sur la question de l'emploi des pronominaux (cf. reprise du titre). J'ai supprimé la notion de déictique, qui effectivement n'était pas appropriée. J'explique mieux ma position concernant le rôle de ces marqueurs (les pronoms) comme indicateurs de stratégies argumentatives : je précise qu'effectivement les marqueurs sont plurifonctionnels. J'ai inséré les exemples en français, car il n'y a pas de traduction possible du 'on' français en anglais : en fait dans l'un des exemples les 'on' sont traduit 'tu'... ce qui complique la présentation; je pense que maintenant les choses sont plus claires (cf. votre remarque sur le rôle joué par You » dans l'exemple traduit en anglais où effectivement You prend dans ce cas la fonction du 'on'. ). Je précise mieux quels sont les marqueurs considérés : par exemple, j'ai traité tous les adverbes (pas seulement les modaux).

Concernant la plurifonctionnalité (où j'ai inséré les références dont les miennes qui ne peuvent qu'attester de ce fait), le fait de traiter sans les différencier les types d'emploi de « je », « tu », « il », « on » peut paraître un problème de fond. Mais justement le fait les trois thèmes ne soient pas égaux quand à la distribution de ces fréquences me paraît intéressant (en fréquence relative au texte- $=$ nombre de marqueurs divisé par le nombre de mos produits-: je précise aussi mieux en ce sens comment je m'y suis prise méthodologiquement : ce n'était pas clair); c'est pour cela que j'étudie au delà du descriptif (figure $\mathrm{n}^{\circ} 1$ ) les co-variations significatives (en fréquence) des emplois de tous les pronoms les uns par rapport aux autres dans chaque contexte de production. J'avoue que ce n'est pas facile à présenter car cela suppose de faire des analyse de régression multiples pour certaines pas à pas pour d'autre en explorant les données en cherchant un modèle linéaire (voir la précision donnée maintenant au plan méthodologique). 
J'ai clarifié la présentation statistique car j'ai harmonisé l'ensemble mention du test de variance $(\mathrm{F}=, \mathrm{p}<$.; pour qu'il y ait unité) : j'ai aussi simplifié les figures qui étaient surchargées, et parfois même redondantes. J'ai pour cela présenter le phénomène de liaison entre l'usage de 'on' et la longueur de production, en catégorisant les textes (on voit beaucoup mieux ce lien).

Je n'ai pas vérifier si les élèves réagissaient de la même manière aux thèmes proposés (degré de polémicité) car la pré-expérimentation normalement sert justement à fixer des thèmes qui étaient significativement différents. Il aurait fallu mesurer cela après l'écriture pour que cela ne biaise pas l'écrit mais je pense que le fait d'avoir déjà écrit justement sur l'un des thèmes aurait influencer leur jugement ? Je pense donc que justement la pré-expérimentation a servi à fixer ces écarts (moraux) entre thèmes. C'est peut-être discutable. Il faudrait pouvoir valider sur un autre échantillon. Ce pourrait être l'occasion d'une autre contribution au domaine. Je suis d'accord sur la remarque concernant la qualité des textes : oui l'étude porte sur la différence d'un thème à l'autre et pose implicitement la qualité de l'écrit (usage du « $\mathrm{j}$ e » des adverbes par els élèves de faible niveau scolaire (voir remarque faite au reviewer $n^{\circ} 1$ à ce propos). Merci d'avoir mis en évidence le fait que je jonglais avec des expressions peu clairs pour le lecteur : contexte de production, thèmes. J'ai aussi choisi la notion de « configuration » à la place de « système » : cela me parait plus juste, eu égard à vos remarques.

Finally the number of revision necessitate a new translation : I have waited for the finance of my laboratory to submit this revision. My excuses for the delay necessary to produce a revision as correctly as possible and conform to your suggestions.

Thank you for your suggestions: they have contributed to engage me in a clear way of revision. 


\begin{abstract}
In our view, the ability to impose moral values which may be, to some extent, either shared or conflictual, influences the strategy adopted when writing argumentative texts. Our hypothesis is that the greater the socio-moral distance between the writers' representations (the writers in this case being children) and those of the recipients (here the parents), the more likely it is that writing will be successful. Three topics derived from a preliminary experiment and corresponding to significant differences in opinion between children and parents were tested in a population of 11-year-old pupils. The pupils had to write a letter designed to convince their parents about one of these topics. We analyzed the texts in order to identify the different configurations in the frequencies of use of the pronouns (frequencies of Je (I), Tu (You), Il (He), On (One/We)) and adverbs. These frequencies differed depending on the topic that was being written about (the moral context that is mobilized).
\end{abstract}


Title: Variation in the use of pronouns as a function of the topic of argumentation in young writers aged 11 years

\section{Emmanuèle Auriac}

- Laboratoire P.A.E.D.I. : Processus d'Action des Enseignants : Déterminants et Impacts, JE 2432, Institut Universitaire de Formation des Maîtres d'Auvergne, Clermont Fd-

- Laboratoire de Psychologie Cognitive et Clinique, EA 3946, Université de Nancy 2-

eauriac@auvergne.iufm.fr ou emma.auriac@wanadoo.fr

Professional address:

I.U.F.M. d'Auvergne

3- Avenue Jean Jaurès

C.S. 20001

63407 Chamalières

France

Personal address:

Rue de la garde

63270 St Maurice es Allier

France 
Insert Figures (1 to 7) and tables (I and II)

Figure 1: dialogical space

DIA-LOGICAL SPACE

To write

\begin{tabular}{|l|}
\hline It-truth (On-Vrai) \\
consensual opinions \\
It, we (On) \\
I (Je)
\end{tabular}

Figure 2: Model letter

Dear Parents, I would like to have TOPIC, but I know you don't agree,

So it would be

great if I had TOPIC.

Figure 3 here: Comparison of the use of markers "I", "You", "On", "He" and adverbs 


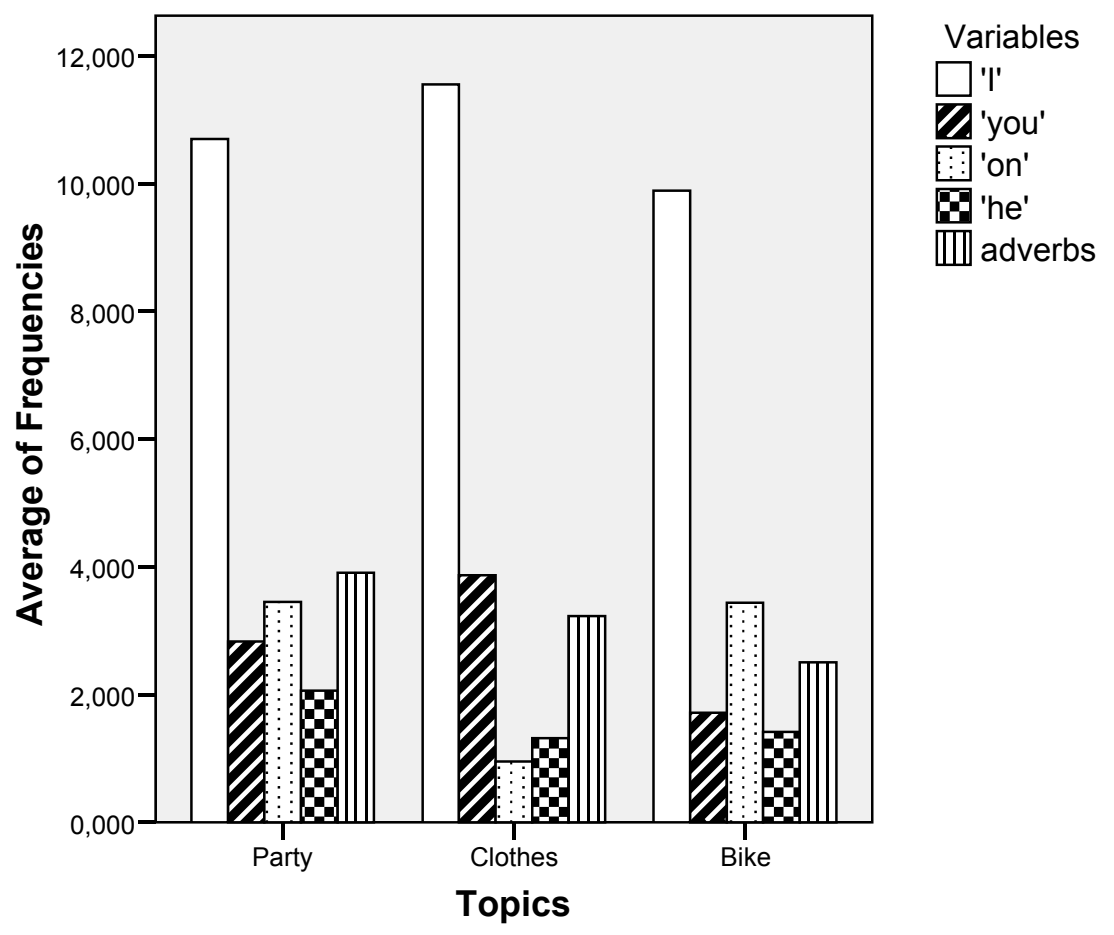

Figure 4: Comparison of the use of "You" and French "On"

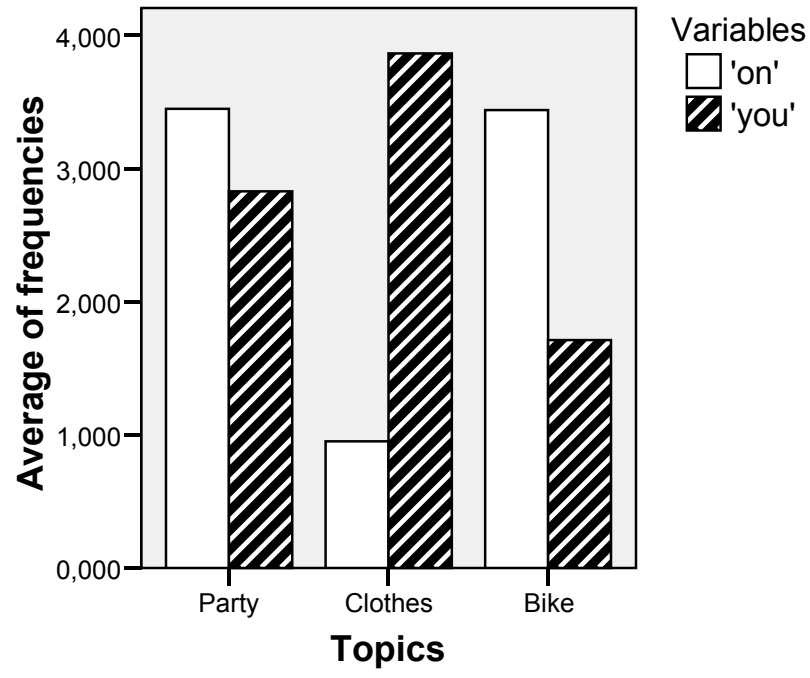

Figure 5: The relations between the pupils' academic levels and the length of the productions (number of words) 


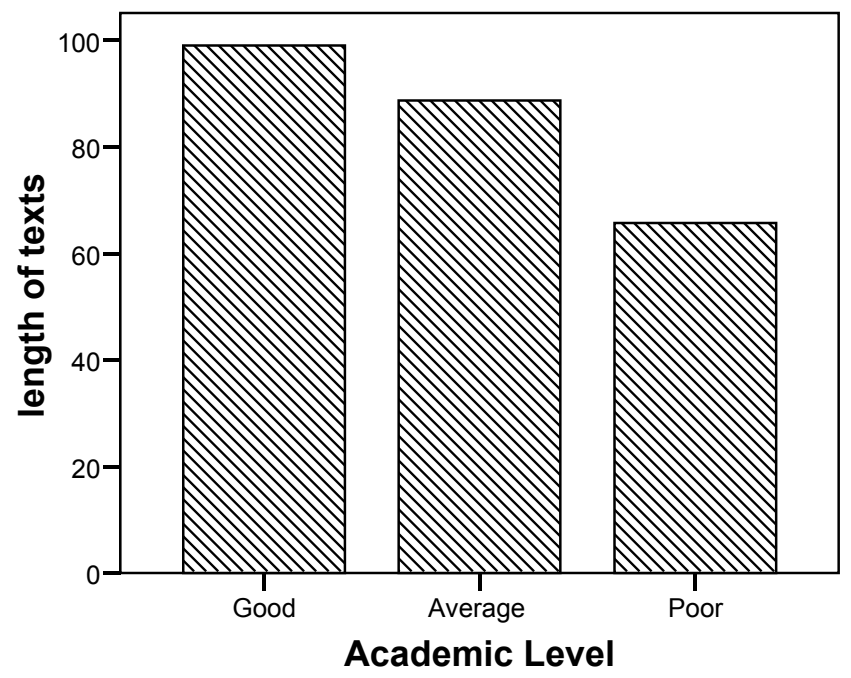

Figure 6: The relation between the use of French 'on' and the length of production (contrast between short texts $-<60$ words- and long texts -60 to 200 words-)

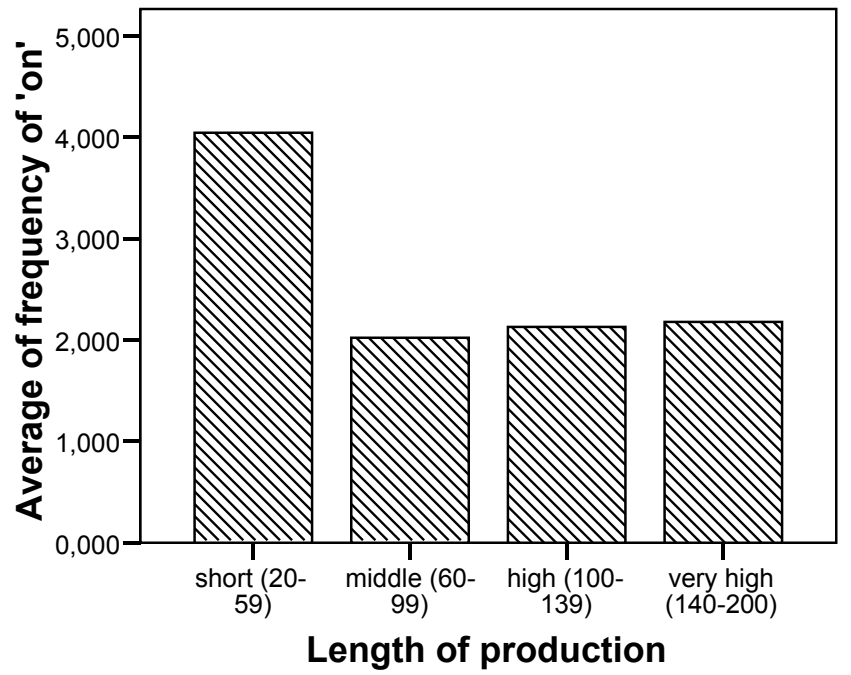

Figure 7: The use of "I" and adverbs as a function of the pupils' academic level 


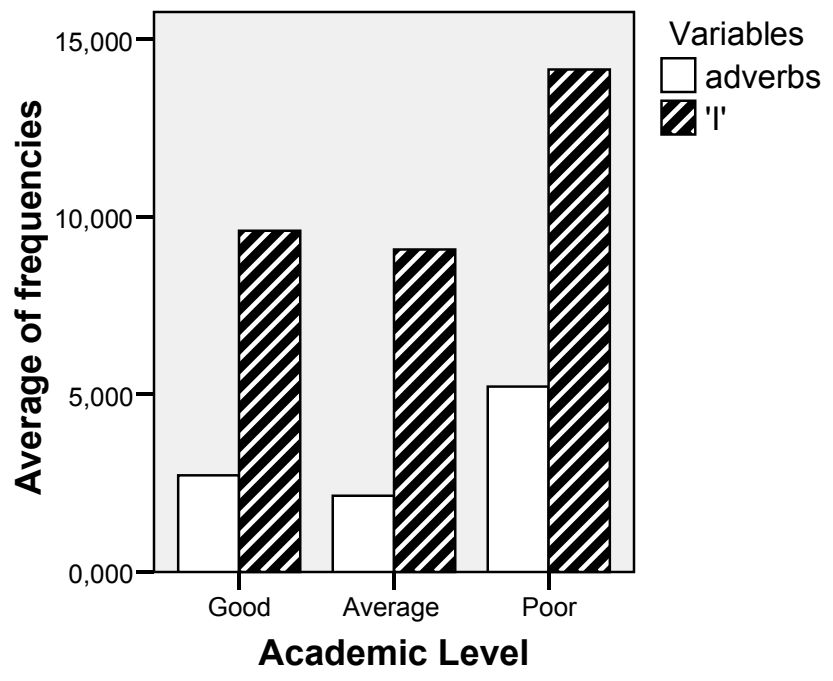

Categories

Table I: The different categories of marker

\begin{tabular}{|l|l|}
\hline I. Deictic & Je moi ma mon (I me my) \\
\hline II. Simple argumentative marker & $\begin{array}{l}\text { Car, parce que, en effet (since, } \\
\text { because, in fact) }\end{array}$ \\
\hline III. Modal adverb & certainement (certainly) \\
\hline IV. Introductory locution & Je pense que (I think that) \\
\hline V. Indefinite Pronoun & On + nous (One, we) \\
\hline VI Counter-argumentative markers & Bien que, même si (even if, even \\
though)
\end{tabular}

Taken from Ghiglione \& Trognon, Où va la pragmatique, 1993 
Table II: Experimental design

\begin{tabular}{|c|c|c|c|}
\hline & Group $1(n=26)$ & Group 2: $(n=27)$ & Group 3: $(n=29)$ \\
\hline & Neutral topic & Average topic & $\begin{array}{c}\text { Highly conflictual } \\
\text { topic }\end{array}$ \\
\hline & BIKE & CLOTHES & PARTY \\
\hline Good level & 11 & 11 & 11 \\
\hline Average level & 9 & 7 & 10 \\
\hline Poor level & 6 & 9 & 8 \\
\hline
\end{tabular}

Key: Experimental factors: Factor $1=$ topics (neutral, average, highly conflictual);

Factor 2=Level (good, average, poor); Dependent variables: number of enunciative markers in each category.

\section{APPENDIX:}

Table III: List of topics in the pre-experiment (extract from Auriac \& Gombert, 2000)

According to you, to dress as you want is:

According to your parents, to dress as you want is:

0

$\begin{array}{lllllll}1 & 2 & 3 & 4 & 5 & 6\end{array}$

$$
\text { Level } 0 \text { = "not good at all..." Level } 6=\text { "really good...." }
$$

\begin{tabular}{|l|l|l|}
\hline \multicolumn{1}{|c|}{ Major difference } & \multicolumn{1}{|c|}{ Average difference } & Small difference \\
\hline $\begin{array}{l}\text { Party until 1 in the } \\
\text { morning (2.36) }\end{array}$ & $\begin{array}{l}\text { Choose your own clothes } \\
\mathbf{( 1 . 2 8 )}\end{array}$ & $\begin{array}{l}\text { Branded trainers } \\
(0.92)\end{array}$ \\
Horror film (2.04) & Walking after school (1.24) & Pocket money \\
Video games (1.84) & Playing late in the street (1.2) & $(0.88)$ \\
Cinema alone (1.8) & Mobile telephone (1.16) & Jeans (0.84) \\
Cutting hair (1.6) & Music and homework (1.12) & Hood (0.8) \\
2 nights with a friend (1.5) \\
Television (1.44) & Risk sports (1.12) & Umbrella (0.76) \\
Friend's homewowk (1.32) & Abroad alone (1.12) & Sweets (1.04) \\
& Key to the house (1.04) & Bike (0.39) \\
\hline
\end{tabular}


Key: the three selected topics are printed in bold type. The topics are listed in descending order as a function of the significant difference in viewpoint between the children and their parents, as perceived by the children.

\section{NOTES}

